\title{
Effect of calcitonin gene-related peptide antagonist on the mortality by nitrate induced tolerance rats with acute myocardial infarction
}

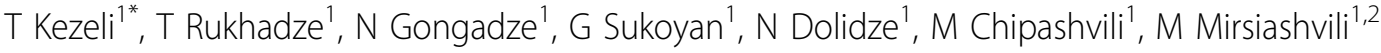 \\ From EPMA-World Congress 2013 \\ Brussels, Belgium. 20-21 September 2013
}

\section{Introduction}

Calcitonin gene-related peptide (CGRP) is one of the most potent vasodilator, which dilates multiple vascular beds, but the coronary circulation is particularly sensitive. The purpose of this study was to evaluate the influence of CGRP antagonist on: 1. Acute mortality; 2. Ventricular arrhythmias and; 3. Prostaglandin $\mathrm{E}_{2}\left(\mathrm{PGE}_{2}\right)$ production by nitrate induced tolerance rats with myocardial infarction (MI).

\section{Methods}

Experiments were carried out in anaesthetized male Wistar rats (BW)-250-300g. MI was induced by ligation of left coronary artery (CAL) resulting in a large anterolateral MI. 3 groups of rats were treated: group 1 received only nitroglycerin (NTG, $50 \mathrm{mg} / \mathrm{kg}$.d, subcutaneous injections b.i.d) 3 days prior to $\mathrm{MI}$; group 2 received NTG in the same dose, route and frequency of administration + CGRP antagonist $\left(\mathrm{CGRP}_{8-37}\right)-10$ $\mathrm{mcg} / \mathrm{kg} 2$ times daily, by similar period of administration; group 3 rats served as normal control (C). ECG tracing in lead II was obtained permanently before induction of MI and up to $60 \mathrm{~min}$ postinfarction. At 60 min postinfarction $1 \mathrm{ml}$ of blood was drawn from the femoral artery for analysis of $\mathrm{PGE}_{2}$ by radio immunoassay.

\section{Results}

CAL after 60 min was accompanied by high incidence of venticular arrhytmias (VA) associated with a significant mortality in group $1(72 \%)$ and especially in group 2
(88\%) rats as compared with $\mathrm{C}$ group of animals (60\%) correlated to profound decrease in $\mathrm{PGE}_{2}$ content more markedly in group $2(2.2 \pm 0.4 \mathrm{ng} / \mathrm{ml})$ vs. group 1 rats $(3.6$ $\pm 0.2 \mathrm{ng} / \mathrm{ml}, \mathrm{p}<0.05)$ and vs. C group $(4.8 \pm 0,3 \mathrm{ng} . \mathrm{ml}$, $\mathrm{p}<0.001)$ respectively.

\section{Conclusion}

It is suggested that CGRP may be important mechanism of nitrate tolerance and diminution availability of CGRP (as potent vasodilator) may lead to exacerbation of acute MI.

\section{Authors' details}

${ }^{1}$ Department of pharmacology, Faculty of Medicine, State University, Tbilisi, Georgia. ${ }^{2}$ Department of pharmacology, State Medical University, Tbilisi, Georgia.

Published: 11 February 2014

doi:10.1186/1878-5085-5-S1-A85

Cite this article as: Kezeli et al:: Effect of calcitonin gene-related peptide antagonist on the mortality by nitrate induced tolerance rats with acute myocardial infarction. EPMA Journal 2014 5(Suppl 1):A85.

\footnotetext{
* Correspondence: tamarakezeli@hotmail.com

'Department of pharmacology, Faculty of Medicine, State University, Tbilisi, Georgia

Full list of author information is available at the end of the article
} 